\title{
Assessment tools for investment attracting factors in rural development
}

\author{
Tatyana Makarova ${ }^{1}$, Yurij Domenko ${ }^{1}$, and Vladimir Plotnikov ${ }^{2 *}$ \\ ${ }^{1}$ Vyatka State University, 36 Moskovskaya str., 610000, Kirov, Russia \\ ${ }^{2}$ St. Petersburg State University of Economics, 21 Sadovaya str., 191023, St. Petersburg, Russia
}

\begin{abstract}
In modern conditions, all phenomena, and socio-economic processes of the functioning of economic entities are interconnected, interdependent and conditioned. When analyzing economic phenomena and processes, we are faced with the multidimensionality of their description, that is, with the need to consider a large number of features. At the same time, it is not always possible to immediately single out the most significant, the main ones. This fact actualizes the need to study both the form of connection between socio-economic phenomena and processes, and the degree of its manifestation. The analysis of the investment attractiveness of rural areas can be carried out, including using the method of factor analysis. The purpose of the article is to develop a tool for assessing the factors of investment attractiveness of rural areas. For this, a factor analysis was carried out to determine the factors that have the greatest impact on the functioning of agricultural enterprises for further work on the formation of a strategic program for the development of agricultural territories. The study was carried out on empirical data from the Northern districts of the Omsk region (Russia). The results obtained will make it possible to develop complex management solutions aimed at regulating the activities of agricultural producers and provide the necessary support measures.
\end{abstract}

\section{Introduction}

Rural areas play an important role in social and economic development [1-3]. These areas make a significant contribution to the economies of countries and regions. At the same time, the share of agricultural production in modern developed economies is relatively small [4]. For example, in the USA agriculture, food, and related industries contributed $5.2 \%$ to the GDP in 2019; direct on-farm employment accounted for about 2.6 million of these jobs, or $1.3 \%$ of US employment (see: https://www.ers.usda.gov/data-products/agand-food-statistics-charting-the-essentials/ag-and-food-sectors-and-the-

economy/\#: :text=Agriculture $\% 20$ and $\% 20$ its $\% 20$ related $\% 20$ industries,percent $\% 20 \mathrm{of} \% 20 \mathrm{t}$ otal\%20U.S.\%20employment.). In developing countries, the share of agriculture in GDP is higher. For example, in Sierra Leone it is $54.34 \%$, in G.-Bissau - 52.54\%, in Chad $42.59 \%$, etc. (see: https://www.theglobaleconomy.com/rankings/share_of_agriculture).

* Corresponding author: plotnikov 2000@mail.ru 
As the economy develops, its structure changes. Underdeveloped economies tend to be agricultural. And the most developed are post-industrial. As economic evolution progresses, the share of agriculture in GDP and the share of agricultural workers are declining [5]. But this does not mean that the importance of agriculture is diminishing. Due to its activities, the vital needs of the population for food are satisfied. Developed agriculture is the basis for ensuring food security, which plays an important role in the stability of society [6].

It should also be noted the important role of rural areas in the socio-cultural development of society, the preservation of its traditions. The problems of the formation and development of human potential in the modern economy are significant [7-9]. Rural areas have specific features. The lifestyle of the rural population is determined by "proximity to the land". Rural social systems are more fragile than urban ones. Therefore, these issues traditionally occupy a large place in public policy. And in international agreements (in particular, those related to the creation of Free Trade Zones), special attention is paid to the support and special regulation of agriculture and the rural population activities.

Therefore, to ensure sustainable development of rural areas and stable agricultural production, a special economic policy is required. One of the key points of this policy is to increase the investment attractiveness of enterprises for the production and processing of agricultural products. To achieve this goal, it is necessary to improve the mechanisms of state support for agricultural producers and increase the investment attractiveness of rural areas.

The problems of rural areas have not only an economic but also a social aspect. With a decrease in the volume of agricultural production, the social systems of rural areas are degrading, and related industries, such as agricultural machinery and chemical production, have begun to stop. This requires the development of special measures aimed at supporting agricultural producers. But this support provided by the authorities is not always effective. Mobilization of private initiative is required. And this is possible if high investment attractiveness is ensured.

The main purpose of the article is to develop a tool for assessing the factors of investment attractiveness of rural areas. For this, a factor analysis was carried out to determine the factors that have the greatest impact on the functioning of agricultural enterprises for further work on the formation of a strategic program for the development of agricultural territories. The study was carried out on empirical data from the Northern districts of the Omsk region (Russia).

\section{Materials and methods}

There are many traditionally used tools for assessing investment attractiveness. These are methods such as data analysis, polling, questioning, interviewing. The authors applied factor analysis to assess the investment attractiveness of the territory. Despite the large number of scientific publications on the state support of the agro-industrial complex, not all these measures consider specific factors influencing the development of a particular rural area [10]. Analysis of the factors affecting the spatial organization of society is very relevant in the modern dynamic world, has great theoretical and applied value and is a powerful tool for cognition and understanding of the mission, goals, structure, functioning features, development trends of existing and projected objects and socio-economic systems.

Researchers from all over the world in recent years have paid special attention to the development of recommendations to support agricultural producers, which is especially important during the crisis in the agricultural sector, including at the global level. Measures of such support are analyzed in the works of Ragulina and Zavalko. The authors consider in 
the work the concept of measures of state support for agricultural producers [11]. Loginov and Stepanyan analysed various approaches to state support for agriculture in Russia, which allows them to develop the most effective solutions and practical recommendations for government bodies [12].

The opinion of researchers in recent publications necessitates the search for more optimal options and approaches to the analysis and assessment of the investment attractiveness of agricultural areas. It is especially important to increase the investment attractiveness of agricultural areas, which will accelerate the socio-economic development of a particular area [13].

The investment attractiveness of agricultural territories is critically important in the context of globalization, tougher competition, and a general crisis in agricultural production. Most of the studies are related to the procedures for assessing the investment attractiveness of a particular region, identifying the number of factors that are important for the formation of investment potential. In this regard, it becomes necessary to develop an optimal method for assessing the investment attractiveness of an agricultural area.

The factor analysis method allows to analyze the possible risks for investment. This method can be applied to determine the factors influencing the development of a separate territory, including agricultural. Moreover, the influence of the established factors can have both positive and negative effects on the socio-economic process. Factor analysis as a multidimensional technique that contributes to the determination of the relationship between the parameters of variables was used in the dissertation research of Semenov. The author, using this method, concludes that he determines 20 indicators that assess the environment or socio-economic conditions, within which organizations of the chemical industry, which belong to the subjects (regions) of the three classification groups of susceptibility, carry out their activities [14].

Deminova determined the reasons for the decrease in the net profit of the organization uses factor analysis, which determines such reasons with an increase in other costs of the organization [15]. The author also, based on deterministic factor analysis and also the method of factor analysis of the two-factor multiplicative model, determines that the factors identified in the work act in different directions. So, for example, a decrease in net profitability is negative, and an increase in capital return is positive.

Pirogova et al. explores the mechanisms of formation of the value of corporations [1618]. This approach considers a set of factors related to human, material, intellectual and other resources. Based on this analysis, an assessment of the company's value is formed, which determines the attractiveness of investments in the business. The same conceptual approach can be used to assess the investment attractiveness of territories.

Makarova defined the algorithm for studying the factors that affect the level of economic security of the region. The author notes that factor analysis makes it possible to identify groups of indicators that have the greatest impact on the level of economic security of the region. Also, the author identifies twelve variables when conducting factor analysis. All variables are assessed by experts with a maximum rating scale of 10 points. Based on this, the types of indicators of resource potential were determined with such indicators as: the presence of natural resources; environmental protection costs; the population of the region; the volume of investments in fixed assets; the number of labour force, etc. [19].

Based on the factorial analysis of the results of assessing the indicators of the region potential and their impact on the level of economic security, the author concludes that the presence of individual resources of the region, including and agricultural, when using new innovative developments will allow the introduction of new modern high-tech industries to improve the quality life of the population and growth of GRP. A new approach to production, which is based on the massive introduction of information technology in industry and the spread of artificial intelligence, is described in the works [20-22]. 
Dinukova and Gunko analysed the factors influencing the development of production systems of the enterprise, considering the digitalization of the economy [23]. In the work of Rakhmatulina, Akhmetshinna and Safiulina the factors that influence the formation of sustainable rates of economic growth and the implementation of a socially oriented strategy are determined [24]. To analyse the development of agricultural territories, factor analysis was used in the study of Patiket al. In this work, the authors analysed the factors influencing the development of agriculture in the country [25].

Analysis of literary sources allows us to talk about the widespread use of factor analysis in economic science. We propose the use of the factor analysis method to assess the investment attractiveness of agricultural areas. The factor analysis method is a method that is used in the conditions of formalization of the research object in the presence of various kinds of indicators. The application of this method consists in studying the relationship between factors, as an enlarged group of indicators. Further management decisions will be applied considering these aggregated indicators.

As estimated factors, it is proposed to use data obtained directly from agricultural producers in the Northern territories of the Omsk region. This will make it possible to determine as accurately as possible what influences the development of farms. Factor analysis is understood as a method of complex and systematic study and measurement of the impact of factors on the value of effective indicators.

Factor analysis stages:

- Analysis goal setting.

- Selection of factors that determine the studied performance indicators.

- Classification and systematization of factors to provide an integrated and systematic approach to the study of their influence on the results of economic activity.

- Determination of the form of dependence between factors and performance indicators.

- Modelling the relationship between performance and factor indicators.

- Calculation of the influence of factors and assessment of the role of each of them in changing the value of the effective indicator.

- Working with a factor model (its practical use for managing economic processes).

The selection of factors for the analysis of a particular indicator is carried out based on theoretical and practical knowledge in a particular industry. In this case, they usually proceed from the principle: the larger the complex of factors is investigated, the more accurate the results of the analysis will be. At the initial stage, it is proposed to conduct a survey of the heads of agricultural organizations and peasant farms in the Northern districts of the Omsk region.

The selected questions were determined by an expert method. The respondents were the heads of the regional level management bodies in the field of agriculture and the researchers of the Vyatka State University. The heads of agricultural enterprises were asked to answer the question about the significance of the influence of each of the factors on the activities of a particular agricultural enterprise and peasant farms from 1 to 10 , where 1 means a slight influence of the factor, and 10 is the maximum value of the factor on the activities of an agricultural organization.

The following factors were suggested:

- Financial support from the state (X1);

- Natural climatic conditions (X2);

- Transport accessibility to sales markets (X3);

- The level of material and technical support (X4);

- The level of purchase prices for products (X5);

- The level of qualified personnel (X6);

- The level of use of new technologies (X7);

- The level of the cost of agricultural products (X8); 
- The level of development of social infrastructure (X9);

- The level of investment attractiveness (X10);

- Tax level (X11);

- Level of competition in agricultural markets (X12).

At the second stage, the survey results were processed using the MiniTab program. This program combines factors by their correlation, that is, the relationship of influence on the object of management. In the future, the planned management decisions should be made considering the results obtained. In this aspect, the method of applying factor analysis can be used to increase the efficiency of investment projects, since we consider the specifics of a particular territory and can be applied on the territory of various regions.

The heads of agricultural enterprises and peasant farms in the Northern districts of the Omsk region were interviewed. The study was conducted in September-October 2020. The study interviewed 16 heads of peasant farms, one head of an agricultural consumer cooperative, two individual entrepreneurs engaged in the production of agricultural products. The direct activities of agricultural producers are plant growing and animal husbandry, both dairy and meat.

Survey of heads of agricultural enterprises through information and communication networks. The results of the survey and the points awarded are presented in Table 1.

Table 1. Results of a survey of heads of agricultural enterprises in the northern regions.

\begin{tabular}{|c|c|c|c|c|c|c|c|c|c|c|c|c|}
\hline & $\mathbf{X} 1$ & $\mathbf{X} 2$ & $\mathbf{X 3}$ & X4 & X5 & X6 & $\mathbf{X} 7$ & X8 & X9 & $\mathbf{X 1 0}$ & X11 & X12 \\
\hline Peasant farm 1 & 10 & 6 & 2 & 6 & 6 & 10 & 7 & 2 & 6 & 1 & 7 & 6 \\
\hline Peasant farm 2 & 1 & 1 & 10 & 5 & 10 & 7 & 1 & 3 & 10 & 10 & 10 & 1 \\
\hline Peasant farm 3 & 2 & 10 & 10 & 10 & 10 & 10 & 10 & 8 & 10 & 7 & 8 & 1 \\
\hline Peasant farm 4 & 5 & 7 & 5 & 5 & 7 & 3 & 1 & 5 & 2 & 3 & 5 & 1 \\
\hline $\begin{array}{l}\text { Individual } \\
\text { entrepreneur } 1\end{array}$ & 5 & 6 & 1 & 6 & 7 & 5 & 5 & 7 & 7 & 8 & 6 & 5 \\
\hline Peasant farm 1 & 1 & 1 & 1 & 5 & 10 & 1 & 1 & 10 & 10 & 10 & 5 & 1 \\
\hline LLC 2 & 1 & 10 & 10 & 5 & 10 & 10 & 10 & 10 & 10 & 10 & 10 & 1 \\
\hline Peasant farm 5 & 8 & 10 & 10 & 10 & 5 & 7 & 3 & 10 & 5 & 5 & 7 & 1 \\
\hline Peasant farm 6 & 10 & 5 & 10 & 5 & 6 & 10 & 5 & 5 & 10 & 10 & 5 & 5 \\
\hline Peasant farm 7 & 7 & 5 & 10 & 10 & 7 & 10 & 5 & 10 & 10 & 5 & 5 & 1 \\
\hline $\begin{array}{l}\text { Agricultural } \\
\text { production } \\
\text { cooperative } 1\end{array}$ & 7 & 7 & 1 & 10 & 10 & 10 & 10 & 5 & 10 & 10 & 10 & 5 \\
\hline Peasant farm 8 & 5 & 5 & 10 & 5 & 5 & 5 & 7 & 5 & 5 & 7 & 5 & 1 \\
\hline Peasant farm 9 & 6 & 5 & 4 & 7 & 6 & 6 & 6 & 6 & 7 & 7 & 7 & 7 \\
\hline Peasant farm 10 & 10 & 10 & 10 & 7 & 5 & 10 & 7 & 5 & 10 & 10 & 10 & 1 \\
\hline $\begin{array}{l}\text { Individual } \\
\text { entrepreneur } 2\end{array}$ & 5 & 5 & 6 & 6 & 6 & 7 & 5 & 5 & 10 & 7 & 7 & 1 \\
\hline $\begin{array}{l}\text { Agricultural } \\
\text { production } \\
\text { cooperative } 2\end{array}$ & 6 & 7 & 7 & 10 & 5 & 7 & 4 & 5 & 5 & 7 & 5 & 1 \\
\hline Peasant farm 11 & 7 & 5 & 6 & 8 & 5 & 6 & 5 & 7 & 7 & 7 & 7 & 1 \\
\hline Peasant farm 12 & 2 & 4 & 8 & 5 & 1 & 10 & 2 & 8 & 7 & 4 & 5 & 1 \\
\hline Peasant farm 13 & 1 & 5 & 3 & 5 & 1 & 8 & 5 & 5 & 5 & 2 & 10 & 1 \\
\hline Peasant farm 14 & 1 & 5 & 10 & 5 & 5 & 10 & 5 & 7 & 10 & 7 & 10 & 1 \\
\hline Peasant farm 15 & 5 & 10 & 2 & 1 & 5 & 10 & 5 & 4 & 6 & 4 & 5 & 5 \\
\hline Peasant farm 16 & 5 & 4 & 6 & 6 & 6 & 7 & 5 & 5 & 10 & 7 & 7 & 1 \\
\hline
\end{tabular}

\section{Results and discussion}

The factor analysis program first calculates the correlation matrix. The greatest correlation relationship of factors is observed if the correlation coefficient is higher than 0.5 . The number of factors can also be determined using the following rule: the percentage of the 
explained factor variance must be greater than $(100 \% / 11=9.09 \%)$, that is, the calculation includes those factors whose share is more than $9.09 \%$. As a result of the study, the program has selected four factors that have the greatest impact on the development of agricultural enterprises. Factor analysis data are presented in Table 2.

Table 2. Results of factor analysis processed in MiniTab program.

\begin{tabular}{|c|c|c|c|c|c|c|}
\hline Variable & Factor 1 & Factor 2 & Factor 3 & Factor 4 & Factor 5 & Factor 6 \\
\hline $\begin{array}{l}\text { Financial support from the } \\
\text { state }\end{array}$ & -0.059 & 0.082 & 0.275 & 0.259 & -0.136 & -0.356 \\
\hline $\begin{array}{l}\text { Natural and climatic } \\
\text { conditions }\end{array}$ & 0.192 & -0.227 & -1.366 & -0.195 & -0.046 & 0.072 \\
\hline $\begin{array}{l}\text { Transport accessibility to } \\
\text { markets }\end{array}$ & -0.192 & -0.375 & 0.050 & -0.092 & 1.377 & -0.023 \\
\hline Logistics level & 0.050 & -0.044 & -0.080 & -0.259 & -0.018 & 1.242 \\
\hline $\begin{array}{l}\text { The level of purchase prices } \\
\text { for products }\end{array}$ & -0.373 & 0.227 & 0.120 & 0.025 & 0.025 & -0.172 \\
\hline Level of qualified personnel & -0.009 & 1.393 & 0.205 & 0.117 & -0.350 & -0.042 \\
\hline $\begin{array}{l}\text { The level of use of new } \\
\text { technologies }\end{array}$ & -0.145 & -0.310 & 0.384 & 0.083 & 0.072 & -0.185 \\
\hline Production cost level & -0.107 & 0.137 & 0.215 & 1.213 & -0.101 & -0.261 \\
\hline $\begin{array}{l}\text { Social infrastructure } \\
\text { development level }\end{array}$ & 0.221 & -0.027 & -0.142 & -0.072 & -0.040 & 0.038 \\
\hline $\begin{array}{l}\text { Investment attractiveness } \\
\text { level }\end{array}$ & 1.124 & 0.011 & -0.183 & -0.091 & -0.195 & 0.047 \\
\hline Competition level & 0.004 & -0.241 & -0.106 & 0.047 & 0.463 & 0.193 \\
\hline Variable & Factor 7 & Factor 8 & Factor 9 & Factor 10 & Factor 11 & \\
\hline $\begin{array}{l}\text { Financial support from the } \\
\text { state }\end{array}$ & 1.366 & -0.211 & 0.490 & 0.139 & 0.457 & \\
\hline $\begin{array}{l}\text { Natural and climatic } \\
\text { conditions }\end{array}$ & -0.269 & 0.137 & -0.124 & -0.487 & -1.296 & \\
\hline $\begin{array}{l}\text { Transport accessibility to } \\
\text { markets }\end{array}$ & -0.126 & -0.042 & -0.561 & 0.101 & -0.651 & \\
\hline Logistics level & -0.384 & 0.195 & -0.249 & -0.247 & -0.366 & \\
\hline $\begin{array}{l}\text { The level of purchase prices } \\
\text { for products }\end{array}$ & 0.202 & -1.355 & 0.185 & -0.101 & 0.711 & \\
\hline Level of qualified personnel & 0.080 & -0.218 & 0.276 & -0.350 & 1.966 & \\
\hline $\begin{array}{l}\text { The level of use of new } \\
\text { technologies }\end{array}$ & 0.105 & 0.079 & 0.182 & 1.514 & 0.273 & \\
\hline Production cost level & 0.279 & -0.034 & -0.051 & 0.117 & 0.659 & \\
\hline $\begin{array}{l}\text { Social infrastructure } \\
\text { development level }\end{array}$ & -0.044 & 0.151 & -0.053 & -0.130 & -2.663 & \\
\hline $\begin{array}{l}\text { Investment attractiveness } \\
\text { level }\end{array}$ & -0.058 & 0.417 & 0.014 & -0.180 & 1.457 & \\
\hline Competition level & -0.400 & 0.163 & -1.543 & -0.191 & -0.788 & \\
\hline
\end{tabular}


The obtained factors correlate with each other, which indicates their importance for agricultural producers. These factors can have a significant impact on the activities of enterprises and thus their investment attractiveness. The results obtained allow us to draw the following conclusions.

For the first factor, there is a correlation between factors such as: the level of purchase prices for products; the level of development of social infrastructure; the level of investment attractiveness. Consequently, this factor can be called an "investment and infrastructure" factor.

For the second factor, there is a correlation between factors such as: the level of qualified personnel; the level of development of new technologies. This factor can be called the "innovative development" factor.

For the third factor, there is a correlation between factors such as: transport accessibility to sales markets; the level of production costs; the level of competition. This group of factors can be called "transport and logistics".

And for the fourth factor, there is a correlation between factors such as: financial support from the state; natural and climatic conditions; the level of material and technical support. This group includes factors that provide conditions for the operation and development of agricultural enterprises and peasant farm in the Northern districts of the Omsk region. You can call this factor as "material".

The main subject of discussion of this article is to identify factors that can affect the development of agricultural areas in the Northern districts of the Omsk region and increase their investment attractiveness. The above material shows that the direct producers of agricultural products indicate the factors that, in their opinion, have the greatest impact on the operation of agricultural enterprises. The identified factors should be considered by the authorities to develop appropriate management decisions to provide support measures to agricultural producers aimed at increasing investment attractiveness. We believe that the method of factor analysis can be used to assess the investment attractiveness of a territory.

These studies also demonstrate the immediate problems of agricultural producers and should be addressed at the regional or specific territory level. Note that this aspect is also the most important component of establishing the specifics of forecasting and managing the factors of investment attractiveness and determines the direction of further research by the authors.

\section{Conclusion}

Factor analysis will expand the traditional approaches to assessing the investment attractiveness of individual territories. These factors can have both a positive and a negative impact on the development of the investment potential of the territory. As a result of the study, four factors have been identified that have the greatest impact on the development of agricultural enterprises in the Northern districts of the Omsk region.

These factors should become key benchmarks in the development of appropriate measures aimed at supporting agricultural producers in the northern territories of the region. In modern conditions, state support is becoming an objective necessity for the survival and development of agriculture, especially in difficult climatic conditions. The analysis made it possible to develop the necessary list of measures and support measures for the development of agriculture in the Northern districts of the Omsk region and an action plan to increase the investment attractiveness of these territories.

Thus, the study of the investment attractiveness of an agricultural area should be aimed at identifying and presenting the competitive advantages of this industry. This should be the focus of the assessment and analysis methodology. 


\section{References}

1. O.B. Bozhkov, I.V. Trotsuk, RUDN Journal of Sociology, 18(4), 731-746 (2018)

2. L.J. Haider, W.J. Boonstra, G.D. Peterson, M. Schlüter, Traps and Sustainable Development in Rural Areas: A Review, World Development, 101, 311-321 (2018)

3. V.P. Nagirna, Ukrainian Geographical Journal, 2018(1), 47-55 (2018)

4. J.M. Alston, P.G. Pardey, Journal of Economic Perspectives, 28(1), 121-146 (2014)

5. S. Brint, Current Sociology, 49(4), 101-132 (2001)

6. V. Plotnikov, Y. Nikitin, M. Maramygin, R. Ilyasov, National food security under institutional challenges (Russian experience), International Journal of Sociology and Social Policy, Vol. 41, No. 1/2, pp. 139-153 (2021), https://doi.org/10.1108/IJSSP-032020-0074

7. A. Belolipetskaya, T. Golovina, A. Polyanin, Y. Vertakova, E3S Web of Conferences, 164, 09005 (2020), https://doi.org/10.1051/e3sconf/202016409005

8. O. Pirogova, R. Nuzhdin, N. Kondrashova, E3S Web of Conferences, 135, 04016 (2019)

9. W.C. Sanderson, W. Lutz, S. Scherbov, The End of World Population Growth in the 21st Century: New Challenges for Human Capital Formation and Sustainable Development, London, Routledge, p. 352 (2013), https://doi.org/10.4324/9781315870571

10. A.A. Polukhin, A.S. Lankin, M.A. Grudkina, Economy, Labor, Management in Agriculture, 2(35), 32-39 (2018)

11. Y. Ragulina, IOP Conference Series: Earth and Environmental Science, pp. 012103 (2019)

12. D. Loginov, V. Stepanyan, State support of agriculture of Russia - search of approaches to build modern, effective model, Engineering for Rural Development. Proceedings, pp. 1140-1146 (2018)

13. V.A. Sokolova, V.V. Shmat, Topical issues of economics and sociology, pp. 106-110 (2020)

14. A.A. Semenov, Ensuring financial security in the management of obligations of organizations of the chemical industry (Thesis, Moscow, 2018)

15. S.V. Deminova, Development of analysis and forecasting of profitability of commercial organizations based on a systematic approach (Thesis, Moscow, 2014)

16. O. Pirogova, V. Plotnikov, Key Competencies as an Enterprise Value Management Tool, Proceedings of the 31st International Business Information Management Association Conference (IBIMA) "Innovation Management and Education Excellence through Vision”, 25-26 April 2018, Milan, Italy, pp. 1716-1721 (2018)

17. O. Pirogova, V. Plotnikov, The Model of Commercial Enterprise Value Managing (Strategic Level), Proceedings of the 33st International Business Information Management Association Conference (IBIMA) "Education Excellence and Innovation Management through Vision 2020”, 10-11 April 2019, Granada, Spain, pp. 928-936 (2019).

18. O. Pirogova, V. Plotnikov, I. Maltseva, The Main Indicators of Fundamental Value in Managing the Commercial Enterprise Development, Proceedings of the 34th International Business Information Management Association Conference (IBIMA) Vision 2025: Education Excellence and Management of Innovations through 
Sustainable Economic Competitive Advantage, 13-14 November 2019, Madrid, Spain, pp. 1759-1765 (2019)

19. T.V. Makarova, Improvement of the mechanism for the development of economic security of the region on the basis of resource potential (Thesis, Moscow, 2019)

20. E.G. Popkova, N.K. Saveleva, A.A. Sozinova, Lecture Notes in Networks and Systems, 155 (2021), DOI: 10.1007/978-3-030-59126-7_48

21. E.G. Popkova, N.K. Savelyeva, A.A. Sozinova, Lecture Notes in Networks and Systems, 155 (2021), DOI: 10.1007/978-3-030-59126-7_188

22. N.K. Savelyeva, A.V. Kuklin, I.P. Lapteva, N.V. Malysheva, On the Horizon, 27(3-4), 239-244 (2019), DOI: 10.1108/OTH-07-2019-0042

23. O.A. Dinukova, N.N. Gunko, Lecture Notes in Networks and Systems, 133, 441-447 (2021)

24. D.K. Rakhmatullina, E.R. Akhmetshina, A.M. Safiullina, Journal of Physics: Conference Series, pp. 012014 (2018)

25. N. Patyka, O. Gryschenko, A. Kucher, M. Hełdak, B. Raszka, Sustainability, 13 (2), 119 (2021) 